\title{
Understory plant response to site preparation and fertiliza- tion of loblolly and shortleaf pine forests
}

\author{
DALE G. BROCKWAY, GALE L. WOLTERS, HENRY A. PEARSON, RONALD E. THILL, V. ClaRK BALDWIN, \\ AND ALTON MARTIN
}

Authors are research ecologist and research range scientist, respectively, USDA Forest Service, Rocky Mountain Research Station, Albuquerque, N.M. 87106; research range scientist, USDA Agricultural Research Service, South Central Research Center, Booneville, Ark 72927; research wildlife biologist, USDA Forest Service, Southern Research Station, Nacogdoches, Tex. 75962; forest biometrician and range technician, respectively, USDA Forest Service, Southern Research Station, Pineville, La. 71360.

\begin{abstract}
In developing an improved understanding of the dynamics of understory plant composition and productivity in Coastal Plain forest ecosystems, we examined the influence of site preparation and phosphorus fertilization on the successional trends of shrubs and herbaceous plants growing on lands of widely ranging subsoil texture in Arkansas, Louisiana, and Texas which are managed for southern pine production. Burn-inject, chop-burn, chop-burn-disk, double-chop, shear-burn, shear-windrow, and shear-windrow-disk site preparation methods were applied in a completely randomized split-plot design to sites with subsoil textures consisting of loam, gravelly-clay, silt, silty-clay, and clay, both fertilized with $73.4 \mathrm{~kg} P / \mathrm{ha}$ and unfertilized. Site preparation method, subsoil texture, and fertilization influenced production of paspalums and other forbs the first growing season following treatment, but no treatment combination affected plant groups in subsequent years. Total herbaceous production increased 24 to 35-fold over pretreatment levels the first growing season after treatment. While site preparation methods had little influence on herbaceous biomass, subsoil texture affected herbaceous production the first year after treatment, with loam subsoils being most productive. Although annual composites were the most abundant herbaceous group the first year after treatment, they were largely replaced by perennial grasses by the third post-treatment growing season. By the seventh growing season following treatment, herbaceous production declined on all subsoil textures with composition and yield approximating pretreatment estimates. Subsoil texture influenced shrub density
\end{abstract}

The authors express their appreciation to Boise Cascade, Cavenham Forest Industries, Inc., Georgia Pacific Corporation, International Paper Company, Manville Forest Products Corporation, T.L. James and Company, Inc., Willamette Industries, USDA Soil Conservation Service and Kisatchie National Forest for contributions of personnel, resources and services in support of this study.

We are also grateful to three anonymous reviewers for comments quite useful in improving this manuscript.

Commercial Products Disclaimer:

The use of trade or firm names in this publication is for reader information and does not imply endorsement by the U.S. Department of Agriculture of any product or service.

Pesticide Precautionary Statement:

Pesticides can be injurious to humans, domestic and wild animals, and desirable plants if they are not handled or applied properly. Use all pesticides selectively and carefully. Follow recommended practices for the disposal of surplus pesticides and pesticide containers.

Manuscript accepted 12 Jan. 1997. only in the first and third growing seasons after treatment. During the first few years after site preparation, herbaceous production appeared inversely related to shrub density. In the first and third post-treatment growing seasons, fertilization significantly increased total herbaceous production and biomass of composites and legumes. But 7 years after application, total herbaceous production and biomass of bluestems, other grasses, and sedges was greater on unfertilized areas. The absence of differences among treatments by the seventh post-treatment growing season indicates an overall long-term similarity in the degree of disturbance caused by application of each method in this ecosystem.

Key Words: interspecific competition, plant succession, herbaceous biomass, disturbance, forest soils, phosphorus

Forest land managers of the Gulf Coastal Plain in Arkansas, Louisiana, and Texas routinely apply a wide array of vegetation control techniques to improve establishment of loblolly pine (Pinus taeda L.). In the southern United States during 199i, pine was planted on over 708,000 ha (Mangold et al. 1992), most of which received some form of site preparation. Major categories of site preparation, which may be used as singular or combination treatments to reduce competition before tree planting, include (1) mechanical manipulation, (2) chemical application, and (3) prescribed fire.

Prescribed fire is known to effectively control small hardwood trees after larger merchantable pines have been harvested (Williamson 1964, Mann 1979). Mechanical manipulation (e.g., shearing, chopping, disking) or herbicide application (alone or in various combinations with fire and mechanical treatments) generally provide a greater degree of vegetation control than when fire is used alone in stands consisting of larger hardwood trees (Trousdell and Langdon 1967, Grano 1970, Trousdell 1970, Cain 1985. Tiarks and Haywood 1986, Slay et al. 1987).

Herbaceous understory plants are also known to respond to site preparation for pine regeneration. Significant changes at the species level were noted, with a differential response of grasses to differing site preparation methods (Schultz 1976). Within 1 year of treatment, the standing biomass of competing vegetation (woody and herbaceous plants) was influenced by site preparation methods (Slay et al. 1987). Herbaceous production increased 
during the first 4 years after fertilization regardless of the level of competition control (Tiarks and Haywood 1986). Twelve years after treatment, greater herbaceous plant yield was reported on control plots than on areas which had been cultivated or cultivated and fertilized (Wolters and Schmidtling 1975).

Although the body of scientific information regarding the response of herbaceous plants to various site preparation methods is developing, currently available information is inadequatc to comprehensively support informed land management decisions concerning the wide array of ecosystem resource values. This study was initiated to further enhance the body of technical information which over time quantifies the response of understory woody and herbaceous plant species to a variety of mechanical, chemical and burning treatments with and without supplemental phosphorus fertilization on forest soils typical of the Gulf Coastal Plain of Arkansas, Louisiana, and Texas. While earlier reports regarded understory plants collectively as "competing vegetation" with respect to regeneration of the pine overstory (Wolters et al. 1995), this study focuses upon the dynamics of individual plant species and groups.

\section{Materials and Methods}

\section{Study Sites}

We conducted this study on the Gulf Coastal Plain of southern Arkansas, northwestern Louisiana, and eastern Texas where the forest land is managed for loblolly and shortleaf pine (Pinus echinata Mill.) production. The climate in this region is characterized as semi-humid subtropical. The frost-free season is approximately 235 days and extends from mid-March to mid-November. Annual precipitation averages about $1,400 \mathrm{~mm}$, with more than $80 \mathrm{~mm}$ incident each month and about $640 \mathrm{~mm}$ arriving during the April through September growing season (Wolters et al. 1977).

Soils in this region are predominantly ultisols with surface $A$ horizons typically ranging from sandy to silty loam. Our study sites were divided into 5 groups based upon the textural class of the $B$ horizon of the dominant soil series. The textural classes, from coarsest to finest, consisted of loam, gravelly-clay, silt, silty-clay, and clay. Ruston (fine-loam, siliceous, thermic Typic Paleudult), Kirvin (clayey, mixed, thermic, Typic Hapludult), Henry (coarse-silty, mixed, thermic Typic Fragiaqualf), Sawyer (fine-silty, siliceous, thermic Aquic Paleudult) and Boswell (fine, mixed, thermic Vertic Paleudaln), respectively, were the representative series for the 5 textural classes. Detailed descriptions of the soils present on these study sites are found in Haywood and Burton (1990).

Overstory vegetation was dominated by a mixture of loblolly pine and shortleaf pine, in substantially varying proportion. Hardwood trees formed a moderately dense midstory consisting predominantly of white oak (Quercus alba L.), southern red oak (Quercus falcata Michx.), post oak (Quercus stellata Wangenh.), sweetgum (Liquidambar styraciflua L.), mockernut hickory (Carya tomentosa (Poir.) Nutt.), blackgum (Nyssa sylvatica Marsh.), flowering dogwood (Cornus florida L.), and red maple (Acer rubrum L.). American beautyberry (Callicarpa americana L.), yaupon (Ilex vomitoria Ait.), greenbriers (Smilax spp.), blueberries (Vaccinium spp.), hawthorns (Crataegus spp.), and a mixture of small hardwood trees were common woody understory species. Little bluestem (Schizachyrium scoparium (Michx.) Nash) was usually the major grass in forest openings. Longleaf uniola (Chasmanthium sessiliflorium (Poir.) Yates) and spike uniola (Chasmanthium laxum (L.) Yates) were associated with little bluestem where the overstory was moderately dense. Both uniola species occurred in nearly pure, though sparse, stands on heavily shaded sites. Many other grasses, legumes, and composites were common but ordinarily produced little herbaceous biomass prior to treatment. Study sites are described in greater detail by Woltcrs et al. (1977) and Haywood and Burton (1990).

Merchantable timber was harvested from 26 selected study sites prior to application of experimental treatments. Following harvest, nonmerchantable woody plants greater than $2.54 \mathrm{~cm}$ diameter at breast height (d.b.h.) averaged about 6,700 stems per ha and contained a mean basal area of $16.5 \mathrm{~m}^{2} / \mathrm{ha}$ (Wolters et al. 1977). Study plots were selected based on the presence of a minimum hardwood density of 1,235 stems/ha and a basal area of 4.6 $\mathrm{m}^{2} /$ ha prior to site preparation.

\section{Experimental Design and Treatments}

A completely randomized split-plot experimental design was established on the 26 study sites. Thirty-five treatments consisting of 7 site-preparation methods applied across 5 subsoil textural classes were replicated twice. Site-preparation treatments were applied to rectangular $43.9 \times 46.3 \mathrm{~m}\left(2,033 \mathrm{~m}^{2}\right)$ plots. In some cases, multiple (but not necessarily all 7) site preparation plots were installed at a single location (for 1 subsoil texture). The sitepreparation treatments consisted of:

1. Burn-inject $=$ Plots were burned to reduce logging slash and residual live plant material. Remaining live pines and hardwoods greater than $2.54 \mathrm{~cm}$ d.b.h. were manually injected with 2,4-D [(2,4-dichlorophenoxy) acetic acid] during the spring. Soil surface disturbance was minimal.

2. Chop-burn = Plots were chopped with a crawler tractordrawn rolling drum chopper and burned after fine fuels had dried.

3. Chop-burn-disk (referred to as chop-disk) $=$ This treatment was the same as the chop-burn method, except after burning, plots were tilled with a crawler tractor-drawn disk.

4. Double-chop $=$ Plots were chopped with a crawler tractordrawn rolling drum chopper and then rechopped after several days to several weeks, usually at an angle perpendicular to the initial chop.

5. Shear-burn $=$ Pine and hardwood trees remaining on the plot were felled by a shearing blade mounted on a crawler tractor and the plot was burned when fine fuels had dried.

6. Shear-windrow = Remaining pine and hardwood trees were felled as with the shear-burn method, then piled into windrows with brush rakes.

7. Shear-windrow-disk (referred to as shear-disk) $=$ This treatment was the same as shear-windrow except the cleared area between windrows was cultivated with a crawler tractordrawn disk.

Each experimental plot was then split into $43.9 \times 15.2 \mathrm{~m}(667$ $\mathrm{m}^{2}$ ) fertilized and $43.9 \times 31.1 \mathrm{~m}\left(1,365 \mathrm{~m}^{2}\right)$ unfertilized portions. The fertilization treatment consisted of a single surface broadcast application of $168 \mathrm{~kg} \mathrm{P}_{2} \mathrm{O}_{5}$ triple superphospate/ha $(73.4 \mathrm{~kg}$ $\mathrm{P} / \mathrm{ha}$ ), prior to planting loblolly pine seedlings (Haywood and Burton 1990).

Loblolly pines $(1+0$ secdlings) were then planted at a $1.8 \times$ $2.4 \mathrm{~m}$ spacing during the winter preceding herbicide injection of hardwoods or in the winter after mechanical site preparation. The first replication of 35 plots at 12 locations was planted during 
winter 1971 and the second replication of 35 plots at 14 locations was planted mostly during winter 1972 and completed during winter 1973

\section{Vegetation Measurements}

Oven-dry weight of herbaceous plant material (by species or species group: bluestems, panicums, paspalums, uniolas, other grasses, rushes, sedges, composites, legumes, and other forbs) was estimated in 20 quadrats $0.89 \mathrm{~m}^{2}$ in size on each split plot using a weight-estimate procedure (Pechanec and Pickford 1937). All grass species other than bluestems, panicums, paspalums, and uniolas were included in the "other grasses" category and forbs other than composites and legumes were included in the "other forbs" category. Density and crown cover of shrubs (shrubs, vines, and hardwood seedlings less than $2.54 \mathrm{~cm}$ d.b.h) were estimated ocularly in four $4.05 \mathrm{~m}^{2}$ circular quadrats on each split plot. Herbaceous production, shrub density and crown cover were sampled during fall of the first, third, and seventh growing seasons after loblolly pine seedlings were planted. Loblolly pine survival and growth data were reported by Haywood and Burton (1990). Identification and scientific nomenclature for plant species are consistent with Grelen and Hughes (1984) and the USDA Soil Conservation Service (1982). Common plant names generally follow those of Grelen and Hughes (1984) and Kelsey and Dayton (1942).

\section{Data Analysis}

Data collected the first and third years after treatment were analyzed by analysis of variance for a split plot design with 2 replications. Main effects plots for each of 5 subsoil textural classes and 7 site-preparation methods were divided into fertilized and unfertilized portions as previously described. Data from replication 2 were not available for analysis in the seventh year, so the analysis was modified to assume negligible interaction and only tested for main effects. Main effects were separated using Scheffe's Test (Steele and Torrie 1980) at the 0.05 probability level. When significant interactions were detected, we combined the interacting variables as a new treatment group for testing by one-way analysis of variance. If the analysis revealed homogeneity of variance, treatment means were tested by Tukey's T-test. Where variance heterogeneity was observed, treatment means were tested by Dunnett's multiple comparison test (Dunnett 1980).

\section{Results and Discussion}

\section{Subsoil Texture Effects}

Subsoil texture significantly influenced aboveground biomass production of bluestems, panicums, paspalums, other grasses, sedges, and other forbs the first growing season following treatment (Table 1). These herbaceous groups were generally more productive on loam subsoil with very low to minimal production on silt subsoil. Paspalums and other forbs were also highly productive on clay subsoil. Broomsedge (Andropogon virginicus L.), arrowfeather threeawn (Aristida purpurascens Poir.), shaggy crabgrass (Digitaria villosa (Walt.) Pers.), violet crabgrass (Digitaria ischaemum var. violascens (Link) Radf.), vaseygrass, brownseed paspalum, gaping panicum (Steinchisma hians (Ell.) Nash), and beaked panicum (Panicum anceps Michx.) were the
Table 1. Subsoil texture influence on herbaceous production the first growing season following treatment.

\begin{tabular}{lccccc}
\hline & \multicolumn{5}{c}{ Subsoil Texture } \\
\cline { 2 - 5 } & loam & $\begin{array}{l}\text { gravelly- } \\
\text { clay }\end{array}$ & silt & silty- \\
& clay & clay \\
\hline Bluestems & $154 \mathrm{a}$ & $30 \mathrm{~b}$ & $25 \mathrm{~b}$ & $206 \mathrm{a}$ & $76 \mathrm{ab}$ \\
Panicums & $297 \mathrm{a}$ & $83 \mathrm{c}$ & $69 \mathrm{c}$ & $85 \mathrm{c}$ & $180 \mathrm{~b}$ \\
Paspalums & $21 \mathrm{ab}$ & $3 \mathrm{~b}$ & $4 \mathrm{~b}$ & $10 \mathrm{ab}$ & $80 \mathrm{a}$ \\
Uniolas & 161 & 109 & 154 & 28 & 27 \\
Other Grasses & $461 \mathrm{a}$ & $62 \mathrm{~b}$ & $46 \mathrm{~b}$ & $71 \mathrm{~b}$ & $63 \mathrm{~b}$ \\
Rushes & 28 & 3 & 7 & 25 & 49 \\
Sedges & $76 \mathrm{a}$ & $13 \mathrm{~b}$ & $29 \mathrm{~b}$ & $55 \mathrm{ab}$ & $62 \mathrm{ab}$ \\
Composites & 1,004 & 1,246 & 1,496 & 1,639 & 1,463 \\
Legumes & 37 & 34 & 19 & 29 & 47 \\
Other Forbs & $420 \mathrm{a}$ & $189 \mathrm{~b}$ & $250 \mathrm{ab}$ & $173 \mathrm{~b}$ & $534 \mathrm{a}$ \\
Total Herbage & 2,659 & 1,772 & 2,099 & 2,321 & 2,581 \\
\hline
\end{tabular}

Means in the same row followed by a different letter are significantly different at the 0.05 level; absence of letters within rows indicates no significant differences.

most common perennial grass species regardless of subsoil texture. Annual and other early invader grasses such as oldfield threeawn (Aristida oligantha Michx.), slimspike threeawn (Aristida longespica Poir.), churchmouse threeawn (Aristida dichotoma Michx.), fringeleaf paspalum (Paspalum setaceum var. cilitifolium (Michx.) Vasey), and hurrahgrass were also common. On gravelly-clay and loam subsoils, paspalums such as roundseed paspalum, dallisgrass, Florida paspalum, field paspalum (Paspalum laeve Michx.), fringeleaf paspalum, and hurrahgrass were quite common, as were other grasses such as purpletop (Tridens flavus (L.) Hitchc.) and purple lovegrass (Eragrostis spectabilis (Pursh) Steud.). Red-top panicum (Panicum agrostoides Spreng.), vaseygrass, and bent-awn plumegrass (Erianthus contortus Baldw. ex Ell.) were more common on silty-clay and clay subsoils. Pinehill beakrush (Rhynchospora globularis (Chapm.) Small) and fringed razorsedge (Scleria ciliata Michx.) were generally the most common sedges on all subsoil textures and rough buttonweed, a low growing early seral species, was the most common other forb on all subsoils the first growing season after treatment.

Composites were the most productive herbaceous group on all subsoils the first growing season following treatment. Dogfennel (Eupatorium capillifolium (Lam.) Small) was dominant on loam, silt, silty-clay, and clay subsoils mixed with lesser amounts of other composites such as annual horseweed (Conyza canadensis var. pusilla (Nutt.) Cronq.), common ragweed (Ambrosia artemesiifolia L.), bitter sneezeweed (Helenium amarum (Raf.) Rock), and tall goldenrod (Solidago altissima L.). Late eupatorium (Eupatorium serotinum Michx.) was dominant on gravelly-clay subsoils the first growing season after treatment with lesser amounts of other composites such as dogfennel, annual horseweed, tall goldenrod, and common ragweed.

Three growing seasons following treatment, bluestems, panicums, paspalums, and sedges continued to be highly productive on loam subsoil with low to minimal biomass production on gravelly-clay and silt subsoil (Table 2). Total herbaceous aboveground biomass was also greatest on loam. From the first to third growing season after treatment, the importance of broomsedge and slender bluestem (Schizachyrium tenerum Nees) increased substantially, as did red top panicum, beaked panicum, and gaping panicum. Invasive carly scral and annual species declined 
Table 2. Subsoil texture influence on herbaceous production the third growing season following treatment.

\begin{tabular}{|c|c|c|c|c|c|}
\hline & \multicolumn{5}{|c|}{ Subsoil Texture } \\
\hline & loam & $\begin{array}{l}\text { gravelly } \\
\text { clay }\end{array}$ & silt & $\begin{array}{l}\text { silty- } \\
\text { clay }\end{array}$ & clay \\
\hline & $\ldots .$. & $\ldots .$. & - (kg/ha) & $\ldots \ldots$ & $\ldots \ldots$ \\
\hline Bluestems & $998 \mathbf{a}$ & $299 \mathrm{~cd}$ & $244 d$ & $720 \mathrm{ab}$ & $497 \mathrm{bc}$ \\
\hline Panicums & $874 a$ & $247 b c$ & $188 \mathrm{c}$ & $237 \mathrm{c}$ & $500 \mathrm{ab}$ \\
\hline Paspalums & $169 a$ & $9 b$ & $22 \mathrm{ab}$ & $34 \mathbf{a b}$ & $55 \mathrm{ab}$ \\
\hline Uniolas & 232 & 241 & 239 & 118 & 75 \\
\hline Other Grasses & 53 & 45 & 44 & 74 & 75 \\
\hline Rushes & $98 \mathbf{a b}$ & $2 c$ & $13 b c$ & $40 \mathrm{~b}$ & $124 a$ \\
\hline Sedges & $128 \mathrm{a}$ & $19 b$ & $39 b$ & $93 \mathrm{ab}$ & $98 \mathrm{a}$ \\
\hline Composites & $142 b$ & $526 a$ & $375 a$ & $480 \mathrm{a}$ & $647 a$ \\
\hline Legumes & 47 & 184 & 123 & 126 & 206 \\
\hline Other Forbs & 155 & 158 & 174 & 252 & 231 \\
\hline Total Herbage & $2,896 a$ & $1,730 \mathrm{bc}$ & $1,461 \mathrm{c}$ & $2,174 b$ & $2,508 \mathrm{ab}$ \\
\hline
\end{tabular}

Means in the same row followed by a different letter are significantly different at the 0.05 level; absence of letters within rows indicates no significant differences.

with time subsequent to site preparation. A similar trend was reported by Haywood et al. (1981). Three to 6 years after herbaceous weed control for loblolly pine regeneration in Alabama, the importance of broomsedge increased while that of annual horseweed diminished (Britt et al. 1991).

Rushes and composites were most productive on clay subsoil, although rushes were equally productive on loam. Composites were least productive on loam subsoils. Other forbs diminished substantially on most sites from the first year after treatment, due largely to a precipitous decline in rough buttonweed.

Shrub density was significantly greater on gravelly-clay subsoil the first and third growing seasons following treatment than on loam subsoil (Table 3). No other differences in shrub density were observed. Whilc shrub crown cover also appeared to be greater on gravelly-clay than on loam subsoil the first and third growing seasons after site preparation, the differences were not significant. Shrub density and crown cover appeared to be inversely related to total herbaceous plant production the first and third years after treatment. Density and crown cover were generally greatest on gravelly-clay subsoil where total herbaceous production was least. Shrub density and crown cover were least on loam subsoil where herbaceous plant production was greatest.

Herbaceous plant production declined substantially on all subsoil textures by end of the seventh growing season following treatment. However unlike in the third growing season, total herbaceous production on silty-clay subsoil significantly exceeded that on loam or gravelly-clay subsoils (Table 4). Herbaceous production declined more slowly with time on the finer textured

Table 3. Subsoil texture influence on shrub density and crown cover.

\begin{tabular}{|c|c|c|c|c|c|}
\hline \multirow[b]{2}{*}{$\begin{array}{l}\text { Year following } \\
\text { Treatment }\end{array}$} & \multicolumn{5}{|c|}{ Subsoil Texture } \\
\hline & loam & $\begin{array}{l}\text { gravelly- } \\
\text { clay }\end{array}$ & silt & $\begin{array}{l}\text { silty- } \\
\text { clay }\end{array}$ & clay \\
\hline Density & \multicolumn{5}{|c|}{$\ldots \ldots \ldots$ (shrus/ha) $\ldots \ldots \ldots$} \\
\hline First & $15,420 \mathrm{~b}$ & $27,634 a$ & $21,889 \mathrm{ab}$ & $20,395 \mathrm{ab}$ & $19,528 \mathrm{ab}$ \\
\hline Third & $12,801 \mathrm{~b}$ & $18,555 a$ & $15,675 \mathrm{ab}$ & $14,603 \mathrm{ab}$ & $13,153 \mathrm{ab}$ \\
\hline Seventh & 13,904 & 14,158 & 18,221 & 13,140 & 11,535 \\
\hline Crown Cover: & \multicolumn{5}{|c|}{$\ldots \ldots \ldots\left(\mathrm{m}^{2} / \mathrm{ha}\right) \ldots \ldots$} \\
\hline First & 3,557 & 7,343 & 6,072 & 5,449 & 5,987 \\
\hline Third & 4,906 & 9,183 & 8,879 & 6,993 & 6,145 \\
\hline Seventh & 11,651 & 9,880 & 14,791 & 9,439 & 8,184 \\
\hline
\end{tabular}

Means in the same row followed by a different letter are significantly different at the 0.05 level; absence of letters within rows indicates no significant differences.
Table 4. Subsoil texture influence on herbaceous production seven growing seasons following treatment.

\begin{tabular}{lccccc}
\hline & \multicolumn{5}{c}{ Subsoil Texture } \\
\cline { 2 - 6 } & loam & $\begin{array}{l}\text { gravelly- } \\
\text { clay }\end{array}$ & silt & silty- \\
& clay & clay \\
\hline Bluestems & $1 \mathrm{~b}$ & $4 \mathrm{~b}$ & $26 \mathrm{ab}$ & $131 \mathrm{a}$ & $43 \mathrm{ab}$ \\
Panicums & 7 & 6 & 4 & 35 & 74 \\
Paspalums & 0 & 0 & $\mathrm{~T}$ & $\mathrm{~T}$ & 4 \\
Uniolas & $71 \mathrm{a}$ & $28 \mathrm{~b}$ & $54 \mathrm{ab}$ & $109 \mathrm{a}$ & $11 \mathrm{~b}$ \\
Other Grasses & 2 & 8 & 2 & 3 & 11 \\
Rushes & $\mathrm{T}$ & $\mathrm{T}$ & 2 & 1 & 19 \\
Sedges & $0 \mathrm{~b}$ & $\mathrm{~Tb}$ & $2 \mathrm{ab}$ & $10 \mathrm{a}$ & $1 \mathrm{ab}$ \\
Composites & $1 \mathrm{~b}$ & $7 \mathrm{~b}$ & $7 \mathrm{~b}$ & $66 \mathrm{a}$ & $55 \mathrm{ab}$ \\
Legumes & 1 & 2 & 10 & 7 & 4 \\
Other Forbs & 1 & 6 & 6 & 21 & 22 \\
Total Herbage & $83 \mathrm{~b}$ & $61 \mathrm{~b}$ & $113 \mathrm{ab}$ & $383 \mathrm{a}$ & $243 \mathrm{ab}$ \\
\hline
\end{tabular}

Means in the same row followed by a different letter are significantly different at the 0.05 level; absence of letters within rows indicates no significant differences.

$\mathrm{T}=$ trace, less than $0.5 \mathrm{~kg} / \mathrm{ha}$.

subsoils. Seven years after treatment bluestems, sedges and composites were more productive on silty-clay than on loam or gravelly-clay subsoils. Pretreatment estimates of production were also greater on silty soils (Wolters et al. 1977). Uniolas were the only herbage group with maximum production on loam subsoil 7 years after site preparation. However, tremendous variation in uniola production on silty-clay subsoil may have obscured true subsoil texture effects. Uniolas were the most productive herbaceous plant group prior to treatment (Wolters et al. 1977). Typically, we would expect longleaf uniola and spike uniola to dominate in greatest proportion on the most heavily shaded sites (Wolters 1974), such as silt and loam subsoils where shrub crown cover was $50 \%$ greater $\left(13,221\right.$ vs. $\left.9,168 \mathrm{~m}^{2} / \mathrm{ha}\right)$ though not significantly different than on other soils.

The influence of subsoil texture on herbaceous plant production was inconsistent and varied with time and species group. Schuster (1967) in eastern Texas also reported that herbaceous plant production was not closely associated with edaphic factors. Depth of the $\mathrm{A}$ horizon and the amounts of silt and clay in the $\mathrm{A}$ horizon and $B$ horizon accounted for only a small proportion of the variation in herbaceous plant production. However, midstory and overstory cover explained a larger proportion of the variation.

Seven growing seasons following treatment, shrub density averaged 14,192 plants per ha and mean crown cover was 10,789 $\mathrm{m}^{2} / \mathrm{ha}$, neither of which were significantly influenced by subsoil texture. Shrub crown cover was similar to pretreatment estimates (Wolters et al. 1977). The density of shrubs was significantly greater on gravelly-clay than on loam the first and third growing seasons after treatment. However, because of the progressive decline in number of shrubs with time, density was similar on all subsoil textures 7 years after treatment. Overall post-treatment shrub density was nearly double the pretreatment estimate (Wolters et al. 1977). Haywood and Burton (1990) reported a significantly greater density of pines at age 12 on silty-clay than on gravelly-clay subsoils. We found an inverse relationship between loblolly pine density at age 12 and shrub crown cover 7 growing seasons after site preparation. Pine density was greatest and shrub crown cover was minimal on silty-clay and clay subsoils, whereas shrub crown cover was greatest and pine density was low on silt and loam subsoils. Herbaceous production, 7 years after treatment, was greatest on subsoils with minimal shrub crown cover and production generally declined with increased shrub crown 
Table 5. Site-preparation method influence on herbaceous production the first growing season following treatment.

\begin{tabular}{lrrrrrrr}
\hline & \multicolumn{5}{c}{ Site-Preparation Method } \\
\cline { 2 - 8 } & $\begin{array}{l}\text { Bum- } \\
\text { inject }\end{array}$ & $\begin{array}{c}\text { Chop- } \\
\text { burn }\end{array}$ & \multicolumn{1}{c}{$\begin{array}{c}\text { Chop- } \\
\text { disk }\end{array}$} & $\begin{array}{c}\text { Double- } \\
\text { chop }\end{array}$ & $\begin{array}{c}\text { Shear- } \\
\text { burn }\end{array}$ & $\begin{array}{c}\text { Shear- } \\
\text { windrow }\end{array}$ & $\begin{array}{c}\text { Shear- } \\
\text { disk }\end{array}$ \\
\hline Bluestems & 194 & 226 & 50 & 47 & 110 & 53 & 13 \\
Panicums & 93 & 152 & 121 & 96 & 176 & 147 & 198 \\
Paspalums & $\mathrm{T}$ & 11 & 19 & 37 & 43 & 33 & 9 \\
Uniolas & 401 & 55 & 29 & 17 & 210 & 26 & 7 \\
Other Grasses & 33 & 155 & 128 & 104 & 235 & 131 & 194 \\
Rushes & $\mathrm{T}$ & 11 & 22 & 13 & 26 & 24 & 49 \\
Sedges & 40 & 55 & 48 & 42 & 46 & 40 & 54 \\
Composites & 846 & 1,751 & 2,110 & 1,700 & 963 & 987 & 1,113 \\
Legumes & 19 & 41 & 27 & 28 & 64 & 26 & 21 \\
Other Forbs & 146 & 204 & 248 & 296 & 308 & 476 & 451 \\
Total herbage & 1,772 & 2,661 & 2,802 & 2,380 & 2,181 & 1,943 & 2,109 \\
\hline
\end{tabular}

Means in the same row followed by a different letter are significantly different at the 0.05 level; absence of letters within rows indicates no significant differences. $\mathrm{T}=$ trace, less than $0.5 \mathrm{~kg} / \mathrm{ha}$.

cover. Similar findings were reported in Georgia by Halls et al. (1956). Wolters et al. (1982) theorized that shrub and hardwood crown cover could influence herbaceous plant production equally or to a greater extent than pine basal area or site quality. Shrubs and hardwood trees sprout prolifically after thinning the overstory or burning and soon appear to limit herbaceous production. Schuster and Halls (1963) and Blair (1968) reported similar findings in eastern Texas.

\section{Site Preparation Effects}

Site preparation methods did not influence production of any herbaceous plant group the first growing season following treatment, although production ranged from about 1,772 to 2,802 $\mathrm{kg} / \mathrm{ha}$ (Table 5). Composites were the most abundant herbaceous group, comprising 45 to $75 \%$ of the total aboveground herbaceous production. Other forbs made up 8 to $25 \%$ of the total herbaceous group the first growing season after treatment. All grasses combined produced less than $25 \%$ of the total herbaceous biomass the first year after treatment. Early seral species such as annual threeawns, violet crabgrass, shaggy crabgrass, spreading panicum, and gaping panicum were the most common grass species on the highly disturbed chop-disk, double-chop, and shear treatments. Broomsedge and slender bluestem were generally the most abundant grasses the first year after site preparation where surface soil disturbance was slight, as with the burn-inject and chop-burn methods.

Total herbaceous production remained fairly constant from the first to the third growing season following site preparation (Table 6). Composites were the only herbaceous plant group significantly influenced by site-preparation method 3 growing seasons after treatment. Composite production was least on the burn-inject treated plots where surface soil disturbance was minimal and generally greatest on the highly disturbed chop and shear treated plots. Tremendous within-treatment variation, particularly on the chop-burn and chop-disk treated plots, likely masked some composite production treatment differences.

The abundance and importance of herbaceous plant groups shifted substantially from the first to third growing season following treatment. Composites, other forbs and other grasses declined by over $50 \%$ on all treatments from the first to the third growing
Table 6. Site-preparation method influence on herbage production the third growing season following treatment.

\begin{tabular}{|c|c|c|c|c|c|c|c|}
\hline & \multicolumn{7}{|c|}{ Site-Preparation Method } \\
\hline & $\begin{array}{l}\text { Burn- } \\
\text { inject }\end{array}$ & $\begin{array}{l}\text { Chop- } \\
\text { burn }\end{array}$ & $\begin{array}{l}\text { Chop- } \\
\text { disk }\end{array}$ & $\begin{array}{l}\text { Double- } \\
\text { chop }\end{array}$ & $\begin{array}{l}\text { Shear- } \\
\text { burn w }\end{array}$ & $\begin{array}{l}\text { Shear- } \\
\text { windrow }\end{array}$ & $\begin{array}{l}\text { Shear- } \\
\text { disk }\end{array}$ \\
\hline & & & & $(\mathrm{kg} / \mathrm{ha})$ & 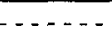 & & - \\
\hline Bluestems & 457 & 551 & 620 & 666 & 466 & 573 & 516 \\
\hline Panicums & 198 & 331 & 315 & 454 & 383 & 468 & 674 \\
\hline Paspalums & 17 & 50 & 25 & 43 & 123 & 85 & 54 \\
\hline Uniolas & 611 & 186 & 99 & 133 & 111 & 160 & 75 \\
\hline Other Grasses & 24 & 39 & 48 & 53 & 106 & 54 & 67 \\
\hline Rushes & 12 & 18 & 16 & 56 & 72 & 86 & 106 \\
\hline Sedges & 54 & 76 & 75 & 69 & 73 & 80 & 89 \\
\hline Composites & $173 \mathrm{c}$ & $461 a b$ & $597 a$ & $466 a b$ & 473ab & $300 \mathrm{~b}$ & $472 a b$ \\
\hline Legumes & 31 & 217 & 174 & 159 & 78 & 130 & 140 \\
\hline Other For & 85 & 123 & 229 & 258 & 207 & 246 & 210 \\
\hline Total Herbage & 1,662 & 2,052 & 2,198 & 2,357 & 2,092 & 2,182 & 2,403 \\
\hline
\end{tabular}

Means in the same row followed by a different letter are significantly different at the 0.05 level; absence of letters within rows indicates no significant differences.

seasons primarily because of the reduction in early seral species such as rough buttonweed, annual horseweed, bitter sneezeweed, and annual threeawns. Other herbaceous groups such as bluestems, panicums, paspalums, uniolas, rushes, sedges, and legumes (consisting primarily of long-lived perennial species) generally increased 2 to 4 -fold from the first to the third year after treatment. Species composition within herbaceous plant groups remained fairly constant. Schultz (1976) reported a 10fold increase in panicums 2 years after burn+disk or burn+disk+bed treatments in northern Florida. However, those treatments significantly reduced production of Curtiss dropseed (Sporobolus curtissii (Vascy) Small).

Shrub density was significantly greater the first and third growing seasons following the chop-burn treatment than after the shear-disk treatment (Table 7). Shrub density was similar following other site-preparation methods. Shrub crown cover was not influenced by the site-preparation method but crown cover tended to be greatest all years following the burn-inject and chop-burn treatments and least following the shear-disk treatment. Shrub crown cover development was intermediate following other sitepreparation methods.

Total aboveground herbaceous plant production declined substantially 7 growing seasons following site preparation to an average of less than $180 \mathrm{~kg} / \mathrm{ha}$ across all treatments. Production ranged from 95 to $425 \mathrm{~kg} / \mathrm{ha}$, but no significant residual treatment effects on production of either individual herbaceous groups or total herbaceous biomass were detected. Uniolas were the most abundant herbaceous group regardless of site-preparation method, but their production ranged only from about 30 to $80 \mathrm{~kg} / \mathrm{ha}$. Bluestems were the next most abundant herbaceous group 7 growing seasons after treatment with an average yield of about 40 $\mathrm{kg} / \mathrm{ha}$. The production of other herbaceous groups was substantially less.

Our findings generally agree with Tiarks and Haywood (1986), who reported a significant increase in dry weight of herbaceous plant material through the fourth year regardless of site-preparation treatment. They also reported a substantial decline in herbaceous production by the sixth year just as we found 7 growing seasons after treatment. In fact, we found herbaceous plant production and composition 7 years after site preparation to be quite 
Table 7. Site-preparation method influence on shrub density and crown cover.

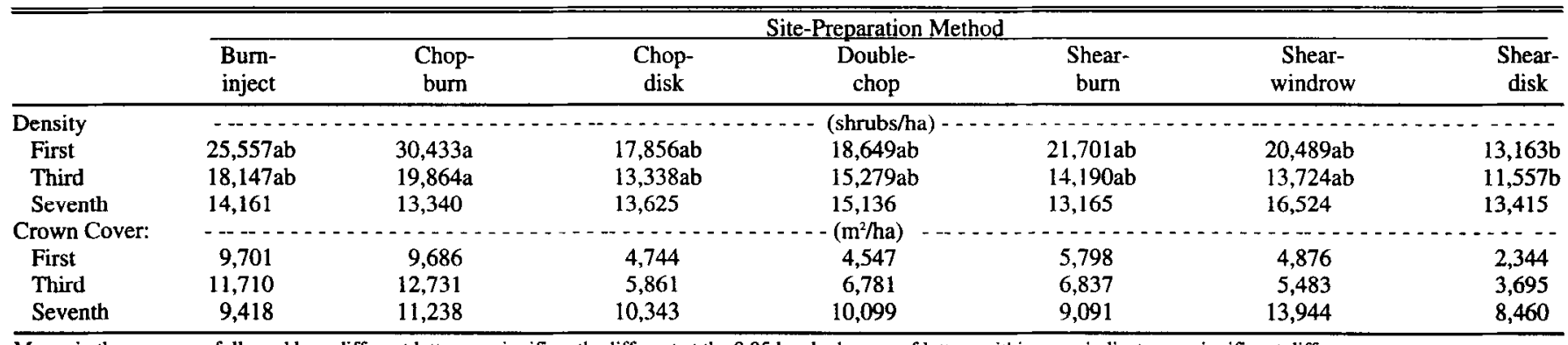

Means in the same row followed by a different letter are significantly different at the 0.05 level; absence of letters within rows indicates no significant differences.

similar to pretreatment production levels reported by Wolters et al. (1977). Increased interception of sunlight by the developing woody plant (shrubs plus pine trees) canopy, accumulation of litter on the forest floor and increasing root competition for site resources very likely produced environmental conditions increasingly less suitable for herbaceous production.

\section{Fertilization Effects}

Phosphorus fertilization significantly increased the production of rushes, composites, legumes, and total aboveground herbaceous biomass the first growing season following treatment (Table 8). Three growing seasons after fertilization, production of composites, legumes, and total herbaceous biomass was still greater on the fertilized than on the unfertilized subplots. Invasive early seral plant species such as annual horseweed, dogfennel, daisy fleabane (Erigeron strigosus Muhl.), bitter sneczeweed (Helenium amarum (Raf.) Rock), fragrant cudweed (Gnaphalium obtusifolium L.), and purple cudweed (Gamochaeta purpurea L. Cabrera) increased in proportion rapidly the first year after treatment, with their response being greatest on fertilized subplots. Annual and perennial composites declined substantially from the first to the third growing seasons after treatment but were still common on both the fertilized and unfertilized areas. Legumes such as arrow crotalaria (Crotalaria sagittalis L.), showy partridgepea (Cassia fasciculata Michx.), and Virginia tephrosia (Tephrosia virginiana (L.) Pers.) responded rapidly to phosphorus fertilization and the carryover effect enhanced legume production for at least 3 years following application.

Table 8. Herbaceous biomass response to phosphorus fertilization.

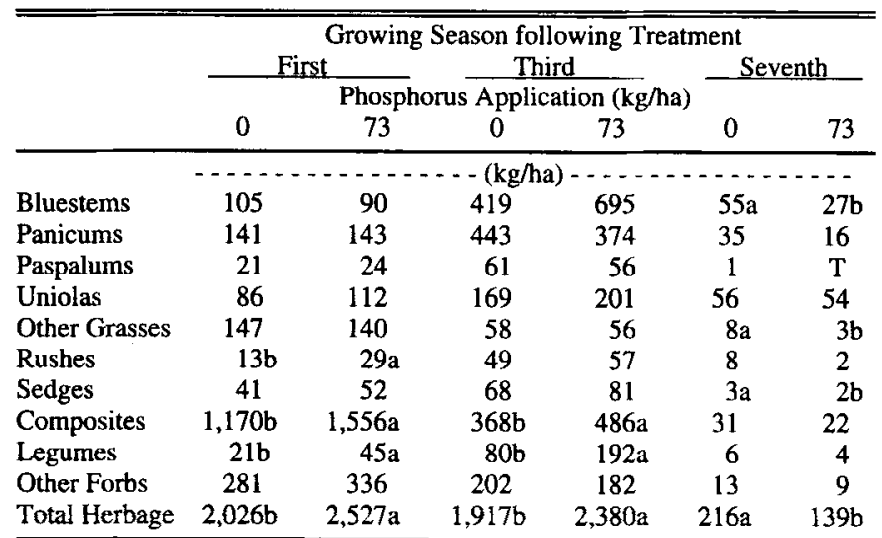

Means in the same row and growing season followed by a different letter are significantly different at the 0.05 level; absence of letters within rows indicates no significant differences.

$\mathrm{T}=$ trace, less than $0.5 \mathrm{~kg} / \mathrm{ha}$.
By 7 growing seasons following treatment, production of bluestems, other grasses, sedges, and total herbaceous biomass was greater on unfertilized subplots. Wolters and Schmidtling (1975) also reported that broomsedge, little bluestem, and some panicums were more productive 12 years after cultivation alone than with cultivation plus fertilization. Only common carpetgrass (Axonopus affinis Chase), an introduced low-growing stoloniferous plant, produced more biomass 12 years after cultivation plus fertilization than with fertilization alone. Our findings suggest that the herbaceous growth benefits from phosphorus fertilization had become lost by 7 years after treatment. Interspecific competition with associated trees and shrubs likely contributed to reduced herbaceous plant production on the fertilized subplots. Phosphorus fertilization significantly increased shrub crown cover on some subsoils 3 years after application and planted loblolly pine d.b.h and volume at age 12 (Haywood and Burton 1990), although fertilizer effects on shrub density and crown cover were not apparent 7 years after application. Similar to our findings with phosphorus, Tiarks and Haywood (1986) reported that a single application of nitrogen, phosphorus, and potassium increased herbaceous production for 4 growing seasons before declining to control levels.

\section{Interactions}

The first growing season following treatment, the influence of site-preparation method on both paspalums and other forbs varied significantly by subsoil texture. Other forbs were also influenced by subsoil texture and phosphorus fertilization. Paspalum production was greater on clay subsoil following double-chop than on all other subsoil texture and site-preparation method combinations except shear-burn on the clay subsoil (Fig. 1). On these 2 clay sites, production ranged from 192 to $271 \mathrm{~kg} / \mathrm{ha}$. Paspalum production on the shear-burn treated clay subsoil was not greater than on the shear-windrow treated clay subsoil or the chop-disk treated silty-clay subsoil. Production of paspalums was generally less than $40 \mathrm{~kg} / \mathrm{ha}$ on all other site-preparation method and subsoil texture combinations. Paspalum production was consistently low on all subsoils the first year following the burn-inject treatment.

Vaseygrass (Paspalum urvillei Steud.), brownseed paspalum (Paspalum plicatulum Michx.), roundseed paspalum (Paspalum circulare (Nash) Poir.), dallisgrass (Paspalum dilatatum Poir.), and Florida paspalum (Paspalum floridanum Michx. var. floridanum) were the most common paspalums on the study plots. However, fringeleaf paspalum (Paspalum setaceum var. ciliatifolium (Michx.) Vasey) and hurrahgrass (Paspalum seteceum var. muhlenbergii (Nash) Banks) increased in greater proportion on clay subsoils following the double-chop and shear-burn treatments. 


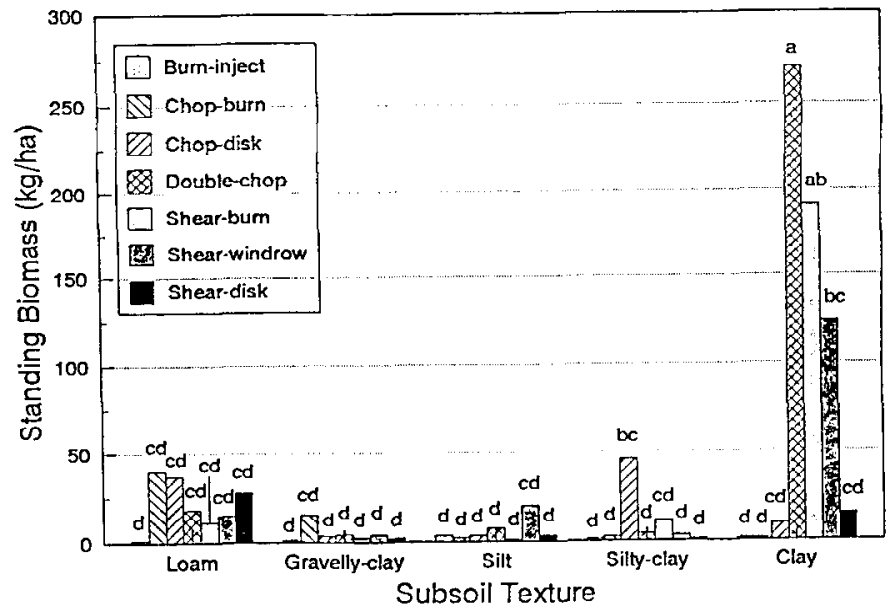

Fig. 1. Paspalum production response to site-preparation method and subsoil texture following the first post-treatment growing season. Means associated with the same letter are not significantly different at the 0.05 level.

Other forbs were most productive on clay subsoil the first growing season following the shear-windrow and shear-disk treatments, although other forbs produced similarly on the double-chop and shear-burn treated clay and loam subsoils after the chop-burn, chop-disk, shear-burn, and shear-windrow treatments (Fig. 2). The method of site preparation appeared to have little influence upon other forb production on silt, gravelly-clay and silty-clay subsoils. Production of other forbs, similar to paspalums, was low following the burn-inject treatment, particularly on gravelly-clay and silty-clay subsoils. Rough buttonweed (Diodia teres Walt.) and woolly croton (Croton capitatus var. capitatus Michx.) were the most common other forb species on treatments resulting in the highest soil disturbance, but occurred infrequently on the burn-inject treatment the first growing season following treatment. Soil disturbance caused by mechanical site-

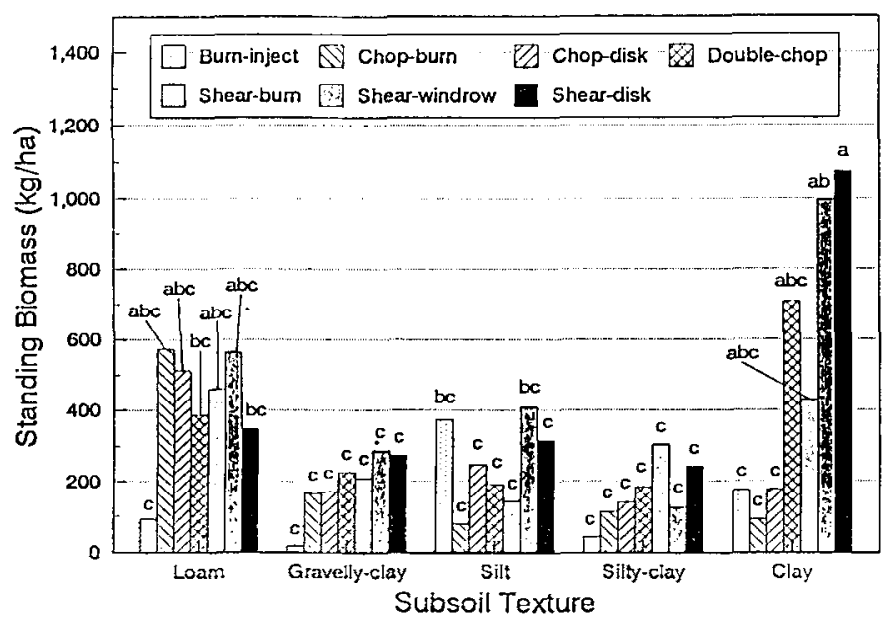

Fig. 2. Production response of other forbs to site-preparation method and subsoil texture following the first post-treatment growing season. Means associated with the same letter are not significantly different at the 0.05 level.

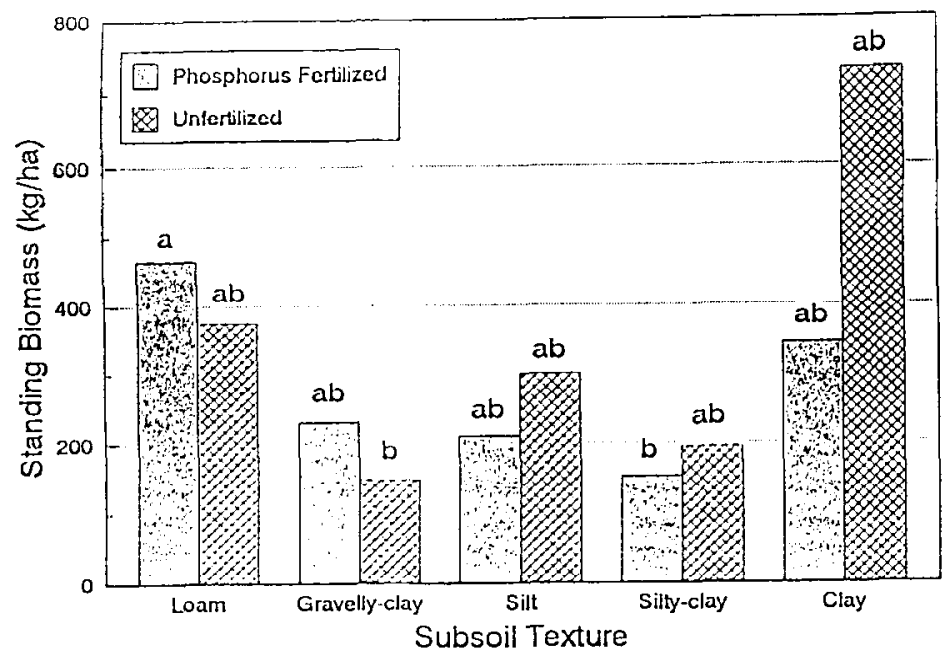

Fig. 3. Production response of other forbs to phosphorus fertilization and subsoil texture following the first post-treatment growing season. Means associated with the same letter are not significantly different at the 0.05 level.

preparation treatments apparently enhanced production of paspalums and other forhs the first year after treatment by stimulating growth of early seral species.

Other forbs were also influenced by subsoil texture and phosphorus fertilizer the first year following treatment (Fig. 3). Other forb production was significantly greater on fertilized loam subsoil than on fertilized silty-clay or unfertilized gravelly-clay subsoils. Because of heterogeneous variance, production of other forbs was similar on all other subsoils with or without phosphorus fertilization.

\section{Summary}

Although production of several herbaceous plant groups was influenced by subsoil texture the first growing season following treatment, invasive early seral and annual composites were the most common species on all subsoils. Annual composites were replaced by perennial grasses 3 growing seasons after treatment. Total aboveground herbaceous biomass production increased 24 to 35-fold over pretreatment levels the first year after site preparation, but method of site preparation did not influence production of any herbaceous plant group. Total herbaceous production remained fairly constant from the first to third post-treatment year, although some shifts occurred in the importance of herbaceous plant groups. Shrub density was greatest on the chop-burn treatment and least on the shear-disk treatment the first and third growing seasons following treatment. A similar trend was observed for shrub crown cover. An inverse relationship was apparent between total herbaceous plant production and both shrub density and crown cover during the first few years after treatment. Seven years after treatment, herbaceous plant production and composition were similar to pretreatment estimates and shrub density and crown cover were similar on all site-preparation treatments. Crown cover was also similar to pretreatment estimates. Phosphorus fertilization increased the production of composites, legumes and total aboveground herbaceous biomass the first and third growing seasons following application. 
However 7 years after application, production of bluestems, other grasses, sedges, and total herbaceous biomass was greater on unfertilized than on fertilized areas. Site preparation and fertilization increased total herbaceous plant production and shrub density on all subsoil textures during the first and third growing seasons following treatment. However, shrub density, crown cover, and total herbaceous plant production declined to near pretreatment levels 7 years after treatment.

\section{Conclusion}

Site preparation and fertilizer application are principally intended to provide a window of opportunity for regeneration and growth of pine overstories in these Coastal Plain ecosystems. Across the range of soil types present, these methods also provided substantial short-term gains in understory plant biomass. Although this increase is primarily represented in the first posttreatment year by larger numbers of early seral species and annual composites, these are largely replaced with perennial grass by the third growing season following treatment. Such rapid successional change is indicative of the resilience of these forest ecosystems following disturbance. While certain site preparation methods reduced shrub density and crown cover more effectively than others, the initial increase in understory herbaceous biomass could not be sustained as shrub redevelopment ensued. Initial gains in understory plant production resulting from fertilization also disappeared over time. The supplemental phosphorus was quite likely rapidly assimilated from these phosphorus-poor soils and immobilized within plant tissue, resulting in progressively slower rates of phosphorus turnover and declining rates of biomass production. The absence of differences among treatments by the seventh post-treatment growing season indicates an overall long-term similarity in the degree of disturbance caused by application of each technique in this ecosystem. These management methods may have caused only short-term plant species displacements, which could be followed by a relatively rapid recovery.

\section{Literature Cited}

Blair, R.M. 1968. Keep forage low to improve deer habitat. Forest Farmer 27:8-9 and 22-23.

Britt, J.R., R.J. Mitchell, B.R. Zutter, D.B. South, D.H. Gjerstad, and J.F.Dickson. 1991. The influence of herbaceous weed control and seedling diameter on six years of loblolly pine growth: a classical growth analysis approach. Forest Sci. 37:655-667.

Cain, M.D. 1985. Long-term impact of hardwood control treatments in mature pine stands. USDA Forest Serv. Southern Forest Exp. Sta. Res. Pap. SO-214. New Orleans, La. 8 pp.

Dunnett, C.W. 1980. Pair-wise multiple comparisons in the unequal variance case. J. Amer. Stat. Assoc. 75(372):796-800.

Grano, C.X. 1970. Small hardwoods reduce growth of pine overstory. USDA Forest Serv. Southern Forest Exp. Sta. Res. Pap. SO-55. New Orleans, La. 8 pp.

Grelen, H.E. and R.H. Hughes. 1984. Common herbaceous plants of southern forest range. USDA Forest Serv. Southern Forest Exp. Sta. Res. Pap. SO-210. New Orleans, La. 147 pp.

Halls, L.K., O.M. Hale, and B.L. Southwell. 1956. Grazing capacity of wiregrass-pine ranges of Georgia. Georgia Agr. Exp. Sta. Tech. Bull. N.S. 2, 38 pp.

Haywood, J.D. and J.D. Burton. 1990. Phosphorus fertilizer, soils and site-preparation influence loblolly pine productivity. New Forest 3:275-287.
Haywood, J.D., R.E. Thill, and J.D. Burton. 1981. Intensive site preparation affects loblolly pine growth on upland sites. Proc. of the Amer. Soc. of Agric. Engineering. Symposium on Engineering Systems for Forest Regeneration, pp. 224-231.

Kelsey, H.P. and W.A. Dayton. 1942. Standardized plant names. 2 nd. ed. J. Horace McFarland Company, Harrisburg, Penn. 675 pp.

Mangold, R.D., R.J. Moulton, and J.D. Snellgrove. 1992. Tree planting in the United States 1991. USDA Forest Serv., State and Private Forestry, Cooperative Forestry, Washington, D.C. 14 pp.

Mann, W.F. 1979. Loblolly-shortleaf pine. In: Silvicultural Systems for the major forest types of the United States. Agr. Handb. No. 445. USDA Forest Serv., Washington, D.C. pp. 95-98.

Pechanec, J.F. and G.D. Pickford. 1937. A weight estimate method for determination of range or pasture production. J. Amer. Soc. Agron. 29:894-904.

Schultz, R.P. 1976. Environmental change after site preparation and slash pine planting on a flatwoods site. USDA Forest Serv. Southeastern Forest Exp. Sta. Res. Pap. SE-156. Asheville, N.C. 20 pp.

Schuster, J.L. 1967. The relation of under-story vegetation to cutting treatments and habitat factors in an east Texas pine-hardwood type. Southwestern Nat. 12:339-364.

Schuster, J.L. and 1.K. Halls. 1963. Timber overstory determines deer forage in shortleaf-loblolly pine-hardwood forests. Proc. Soc. Amer. Foresters - 1962:165-167.

Slay, J.M., B.G. Lockaby, J.C. Adams, and C.G. Vidrine. 1987. Effects of site preparation on soil physical properties, growth of loblolly pine and competing vegetation. Southern J. of Appl. Forestry $11(2): 83-86$.

Steele, R.G.D. and J.H. Torrie. 1980. Principles and procedures of statistics: a biometrical approach. 2nd. ed. McGraw-Hill Book Co., New York. 633 pp.

Tiarks, A.E. and J.D. Haywood. 1986. Pinus taeda L. response to fertilization, herbaceous plant control, and woody plant control. Forest Ecology and Manage. 14:103-112.

Trousdell, K.B. 1970. Disking and prescribed burning: sixth-year residual effects on loblolly pine and competing vegetation. USDA Forest Serv. Southeastern Forest Exp. Sta. Res. Note SE-133. Asheville, N.C. $6 \mathrm{pp}$.

Trousdell, K.B. and O.G. Langdon. 1967. Disking and prescribed burning for loblolly pine regeneration. J. Forestry 65:548-551.

USDA Soil Conservation Service. 1982. National list of scientific plant names. Volume 1. USDA Soil Conservation Service TP-159. Washington, D.C. 416 pp.

Williamson, M.J. 1964. Burning does not control young hardwoods on shortleaf pine sites in the Cumberland Plateau. USDA Forest Serv. Central States Forest Exp. Sta. Res. Note CS-19. Columbus, Ohio. 4 pp.

Wolters, G.L. 1974. Longleaf uniola and spike uniola require shade. J. Range Manage. 27:45-47.

Wolters, G.L. and R.C. Schmidtling. 1975. Browse and herbage in intensively managed pine plantations. J. Wildlife Manage. 39:557-562.

Wolters, G.L., A. Martin, and W.P. Clary. 1977. Timber, browse, and herbage on selected loblolly-shortleaf pine-hardwood forest stands. USDA Forest Serv. Southern Forest Exp. Sta. Res. Note SO-223. New Orleans, La. 9 pp.

Wolters, G.L., A. Martin, and H.A. Pearson. 1982. Forage response to overstory reduction on loblolly-shortleaf pine-hardwood forest range. J. Range Manage. 35:443-446.

Wolters, G.L., H.A. Pearson, R.E. Thill, V.C. Baldwin, and A. Martin. 1995. Response of competing vegetation to site preparation on west gulf coastal plain commercial forest land. USDA Forest Serv. Southern Forest Exp. Sta. Gen. Tech. Rep. SO-116. New Orleans, La. $8 \mathrm{pp}$. 